\title{
Analysis of Temporal Change Taking Place at the Coastline and Coastal Area of the South Coast of the Marmara Sea
}

\section{Marmara Denizi Güney Kıyılarında Kıyı Çizgisi ve Kıyı Alanda Meydana Gelen Zamansal Değişim Analizi}

\section{Sümeyra KURT ${ }^{1}$}

\begin{abstract}
Owing to the fact that determining the temporal change at the coastline is highly significant in maintaining sustainable coastal development plans, this study focuses on the temporal coastline change in the south coasts of the Marmara Sea, which is one of the seas where coastal use and change are the most obvious. Therefore, old and new coastlines have been determined by using Landsat TM images with $30 \mathrm{~m}$ resolution from the years 1984, 2003 and 2011 as well as colorful orthophotographs of the year 2008 with $0,45 \mathrm{~cm}$ resolution. Geometrical confirmation of satellite images were effectuated by using software and techniques of Erdas Imagine 10 and ArcGis 10 and then the coastal analyses from the obtained coastlines and land examinations have been conducted. According to the result of the study, an area of $5,76 \mathrm{~km}^{2}$ have been filled between Çanakkale-Çardak and Yalova within 27 years of time between the years 1984 and 2011. The study also reached a conclusion that mining sand was effectuated in an area of 1,15 $\mathrm{km}^{2}$ and thus the coast was pulled back. The line that was $521 \mathrm{~km}$ in 1984 reached 560 $\mathrm{km}$ in 2011. The most obvious coastal change was seen to be in the coasts of Yalova, Gemlik, Mudanya and Bandırma. The coastal bend, located in Lapseki, Gönen, Karacabey and in the south of Kapıdağ Peninsula, still remains to be a natural coastline. Even though irregular settlements in the coastal areas of cities cut off people's contact with the sea, the solution of filling the coasts was found for the purpose of recreating green spaces in the interest of the public. However, the coastal areas, which have sensitive ecological features, face with pressures of tourism and urban-based developments due to these landfills in the coasts. Therefore, coastal landfills in the southern coasts of the Marmara Sea gradually destroy the natural coastal spaces and the coastline also lost its original appearance.

The population growth and pressures on using the land in the coastal areas have always continued and will continue in the future. Hence, it is essential have new regulations and sustainable permanent plans for long term uses in the future.
\end{abstract}

Key Words: Coastline Change, Coast Area Change, Marmara Sea, Remote Sensing (RS), Geographic Information Systems (GIS).

\footnotetext{
${ }^{1}$ Dr., e-mail: sumeyrakurt@hotmail.com
} 


\section{Özet}

Kıyı çizgisinde zamana bağlı değişiminin belirlenmesi sürdürülebilir kıyı gelişim planlarının yapılmasında büyük önem taşımaktadır. Bu çalışmada kıyı kullanım ve değişiminin en belirgin olarak yaşandığı denizlerimizden birisi olan Marmara Denizi'nin güney kıyılarında zamana bağlı kıyı çizgisi değişimi belirlenmiştir. Bu amaçla 1984, 2003 ve 2011 yıllarına ait $30 \mathrm{~m}$ çözünürlüklü Landsat TM uydu görüntüleri ile 2008 yılı 0,45 cm çözünürlüklü renkli ortofotolar kullanılarak eski ve yeni kıyı çizgileri tespit edilmiştir. Erdas Imagine 10 ve ArcGis 10 yazılım ve teknikleri kullanılarak uydu görüntülerinin geometrik doğrulaması yapılmış ve daha sonra elde edilen kıyı çizgilerinden ve arazi incelemelerinden kıyı değişimi analiz edilmiştir. Çalışma sonucunda 1984 ve 2011 yılları arasında geçen 27 yıllık sürede Çanakkale-Çardak ile Yalova arasında 5,76 km²'lik alan doldurulurken, $1,15 \mathrm{~km}^{2}$ alandan da kum alınarak kıyının geriletildiği tespit edilmiştir. 1984 yılında 521 km olan çizgisi de 2011 yılında 560 km'ye ulaşmıştır. Sahada en belirgin kıyı değişimin Yalova, Gemlik, Mudanya ve Bandırma kıyılarında olduğu görülmüştür. Lapseki, Gelibolu, Gönen, Karacabey ve Kapıdağ Yarımadası'nın kuzeyinde kıyı şeridi doğal kıyı olma özelliğini korumaktadır. Kıyı alanlarındaki düzensiz yerleşim, deniz ile insanların temasının kesilmesine neden olduğundan, kıyılarda kamu yararına yeşil alanların tekrar oluşturulması amacıyla kıyıya dolgu yapılması çözümü bulunmuştur. Ancak, kıyılara yapılan dolgular, hassas ekolojik özellikli kıyı alanlarının turizm ve kentsel kaynaklı gelişmelerin baskısı ile karşı karşıya kalmasına sebep olmuştur. Bu nedenle Marmara Denizi güney kıyılarında kıyı dolgu alanları ile yavaş yavaş doğal kıyı mekânı yok edilerek, kıyı çizgisi de asli görünümünü kaybetmiştir. Bu nedenle Marmara Denizi güney kıyılarında kıyı dolgu alanları ile yavaş yavaş doğal kıyı mekânı yok edilerek, kıyı çizgisi de asli görünümünü kaybetmiştir.

Görünen o ki kıyı alanlarında nüfus artışı ve kullanıma yönelik baskılar, sadece geçmişte ve günümüzde değil, aynı zamanda gelecekte de devam edecektir. Bu nedenle kıyı alanlarının gelecekte uzun süreli kullanımlar için sürdürülebilir ve kalıcı planlama ve yeni düzenlemelerin yapılması gerekmektedir.

Anahtar Kelimeler: Kıyıçizgisi Değişimi, Kıyı Alanı Değişimi, Marmara Denizi, Uzaktan Algılama (UA), Coğrafi Bilgi Sistemleri (CBS).

\section{Introduction}

Coastal regions, defined as transition zones (FInkl, 2004; Boak et al., 2005) are the most populous places of the world due to their industry, commerce, fishing, economic development and ecological characteristics (Anfuso et al., 2013). Today, more than about $50 \%$ of the world's population lives within the section covering 200 kilometers of the coastline because of their favorable features. For example, approximately $53 \%$ of the population in the United States and $86 \%$ of the Australian population reside along the coast (Cardille et al., 2003; Crowel et al., 2007; Scarfe et al., 2009). This increase of population in the coastal regions continues with each passing day particularly in the coasts of North America, Southeast Asia, India and South America. The coastal population in the United States is expected to reach 166 million in 2015 (Klemas, 2009; Anilkumar, 2010). Studies have demonstrated that a similar situation can also be seen in Europe. 200 million people, out of almost 680 million in Europe, continue to live within the coastal zone of $50 \mathrm{~km}$ (Duru, 
2001). The population in the coastal regions is expected to increase about $75 \%$ in 2025 (Crowel et al., 2007; Scarfe et al., 2009).

This excessive population growth and settlement in the coastal regions causes the emergence of irreparable and difficult environmental problems such as the destruction of nature, inadequate infrastructure and transportation system, excessive and improper use of resources, unconscious land and water use and the destruction of green areas (Özdemir, 2004). Improperly studied engineering structures be built near lakes, land reclamation and changes in the ecological balance that will happen due to urban, agricultural and industrial waste disposal have led to deterioration in the balance and morphological structures of these areas (Saïdi et al., 2010; Saïdi et al., 2012). Natural recreation resources, which are open to the public, continue to diminish with each passing day since other problems, such as noise and environmental pollution, brought by urban life due to technological developments, have turned people towards common areas in the coastal regions (Alonso and Cabrera, 2008).

The population growth in coastal regions and economic pressures did not only continue in the past or still continue in the present, but will also continue in the future. Therefore, there is a need for sustainable and permanent planning and new regulations for the long-term recreational use of coastal areas in the future (Brommer and Bochev, 2009). The problem is attempted to be resolved in Turkey by developing solutions like filling the coasts for recreational uses except for transportation purposes. The most obvious example of this can be seen in the coasts of İstanbul on the north of Marmara Sea. İstanbul, one of the most significant metropolitan cities of the world with its cultural and historial values, and especially its coasts in Bosphorus are under intense pressure of settlement due to excessive population growth (Demirci et al., 2009). As a result of this, the inhabitants of İstanbul are deprived of coastal and marine use for recreational purposes. Coasts were filled by İstanbul Metropolitan Municipality through many arrangements in the period after 1984 in order to let the public benefit from coasts as much as needed and the recreational uses were strived to be ensured in the acquired areas. An area of $1687 \mathrm{~km}$ was filled and organized between 1987 and 2007 for this purpose (Kurt et al., 2010).

There are 28 provinces with coastal lines in Turkey, a country encircled by seas on three sides. The total population of these provinces, which was 41.847821 people in 2013 , constituted $54.5 \%$ of the country's population which is 76.667864. 22.076466 people live in the coastal provinces (Çanakkale, Balıkesir, Bursa, Yalova, Kocaeli, İstanbul and Tekirdağ) of the Sea of Marmara which also includes the research area (TSI, 2014). However, coasts have faced with serious destruction particularly in recent years by planning practices that were made without taking the natural features into consideration and their natural appearances as well as coastal lines have been altered. Therefore, it is necessary to carry out works that are aimed at protecting these natural resources (Doğaner, 1992, Doğaner, 2001; İtem and Karaman, 2004, Sayıstay, 2006; Sesli et al., 2007; Akova, 2009; Özşahin and Ekinci, 2012) that were 
damaged due to rapid population growth and settlement connected industrialization and can not be renewed, to approach problems through farsighted perspective, to make accurate and sustainable planning and to implement necessary solutions in place and on time. The fillings made in coasts are needed to be identified in order to make a sustainable planning for the coastal regions of the Sea of Marmara. However, the amount of these fillings made in the coasts and for what purposes they were used can be determined by means of the analysis carried out through appropriate and correct methods. Today, Geographic Information Systems (GIS) and Remote Sensing (RS) methods are widely used for making these determinations. At the same time, Remote Sensing method is one of the most efficient methods used in coastal changes (Vinodkumar et al., 1998; Zhu, 2001, Kostiuk, 2002; Demirci et al., 2009).

There have been many studies on the Marmara Sea Doğaner, 1992, Doğaner, 2001; İrtem and Karaman, 2004, Sayıstay, 2006; Sesli et al., 2007; Akova, 2009; Saïdi et al., 2010; Özşahin and Ekinci, 2012). In this study, identifying old and new coastallines in the southern coasts of the Sea of Marmara and fillings made in a period of 27 years was aimed by using Principal Component Analysis, one of the Remote Sensing (RS) methods. Landsat satellite imagery with the resolution of $30 \mathrm{~m}$ for 1984, 2003 and 2011 and color orthophotos of 2008 with resolution of $0,45 \mathrm{~cm}$. The areas with filling and changes that occured in coasts due to coastal erosion and sand mining were identified as a result of the study by determining temporal change in coastallines. Therefore, this study is significant base for future studies to be conducted on the planning of a sustainable coastal use in the Sea of Marmara.

\section{Study Area}

According to the Geographic Coordinate System, the research area, which lies between $26^{\circ} 09^{\prime} 49^{\prime \prime}-30^{\circ} 22^{\prime} 40^{\prime \prime}$ eastern longitude and $40^{\circ} 00^{\prime} 00^{\prime \prime}$ $41^{\circ} 18^{\prime} 45^{\prime \prime}$ northern latitudes and extends through a coastal area of $500 \mathrm{~km}$, encompasses H17, H18, H19, H20, H21, H22, G19, G21, and G22 sheets in the topographic map of Turkey with $1 / 100000$ scale (Figure 1). The area starts from Çanakkale-Çardak in southwest of the Marmara Sea and extends until YalovaKocaeli provincial border in the east. The study was conducted in the coasts of Çanakkale, Balıkesir, Bursa and Yalova with a population of 426.181 (TSI, 2014), situated in the southern shores of the Marmara Sea. 


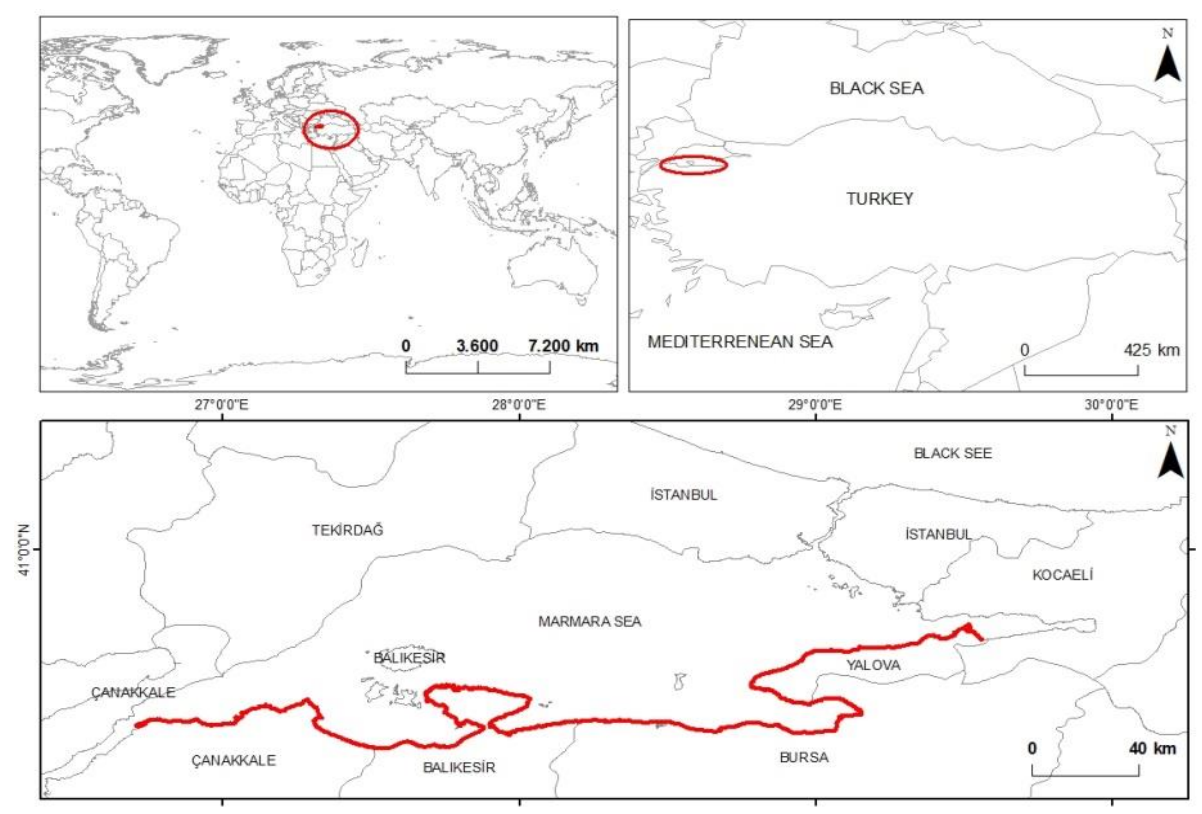

Figure 1: Location Map of the Study Area.

\section{Materials and Methods}

Landsat (TM) satellite imagery, obtained from USGS Global Visualization Viewer (GloVis) for discovering the coastal lines and comparing the change in an accurate way, constituted the main data source of the study. Non-cloud images belonging to different months were preferred for preventing the change perception error brought by the seasonal variations. These images, which have been analyzed in total of 3 periods since 1984, have spatial resolution of $30 \mathrm{~m}$ (Table 1; Figure 2). The display processing analyses of these images were carried out by using Remote Sensing and Geographic Information Systems technologies. Information on changes occurred in the coast due to fieldwork and the active use of coastline were collected.

Satellite images are widely used in determining many environmental problems today by converting them into numerical or visual images. In display systems, at what level the environmental problems of the past and the present have been can be calculated in a detailed manner by satellite images that were subjected to the enrichment and classification processes (Gazioğlu, 1997). GIS and Remote Sensing techniques, together with satellite images are widely used today in determining enviromental problems that occur in coasts and changes in land covers since coastal areas are places where population and urbanization are very intensive (Cardille and Foley, 2003). Some of the Remote Sensing techniques are Digital photogrametry, the Principal Component Analysis (PCA), Normalized Difference Vegetation Index (NDVI), Classification, Tasseled Cap (TC) transformation method (Genç et.al., 2010). 
Table 1: Features of Satellite Images used in the Study.

\begin{tabular}{cccc}
\hline Satellite & Perception Date & Resolution (m) & Number of Band \\
\hline Landsat - 5 TM & 1984 - TM & 30 & 7 \\
Landsat - 5 TM & 2003 - TM & 30 & 7 \\
Landsat - 5 TM & 2011 - TM & 30 & 7 \\
\hline
\end{tabular}

The data obtained from satellites make a major contribution to the study of the earth. The software, which was used because they both brought great impetus to data processing and helped in the storage of a large volume of data, had also proved to be significant in the realization of this contribution (Maktav, 1993). Therefore, all the data obtained in the study were evaluated by Erdas Imagine 10 software program which is a remote sensing sotware and then, they were also analyzed in GIS ArcGIS 10 software program.

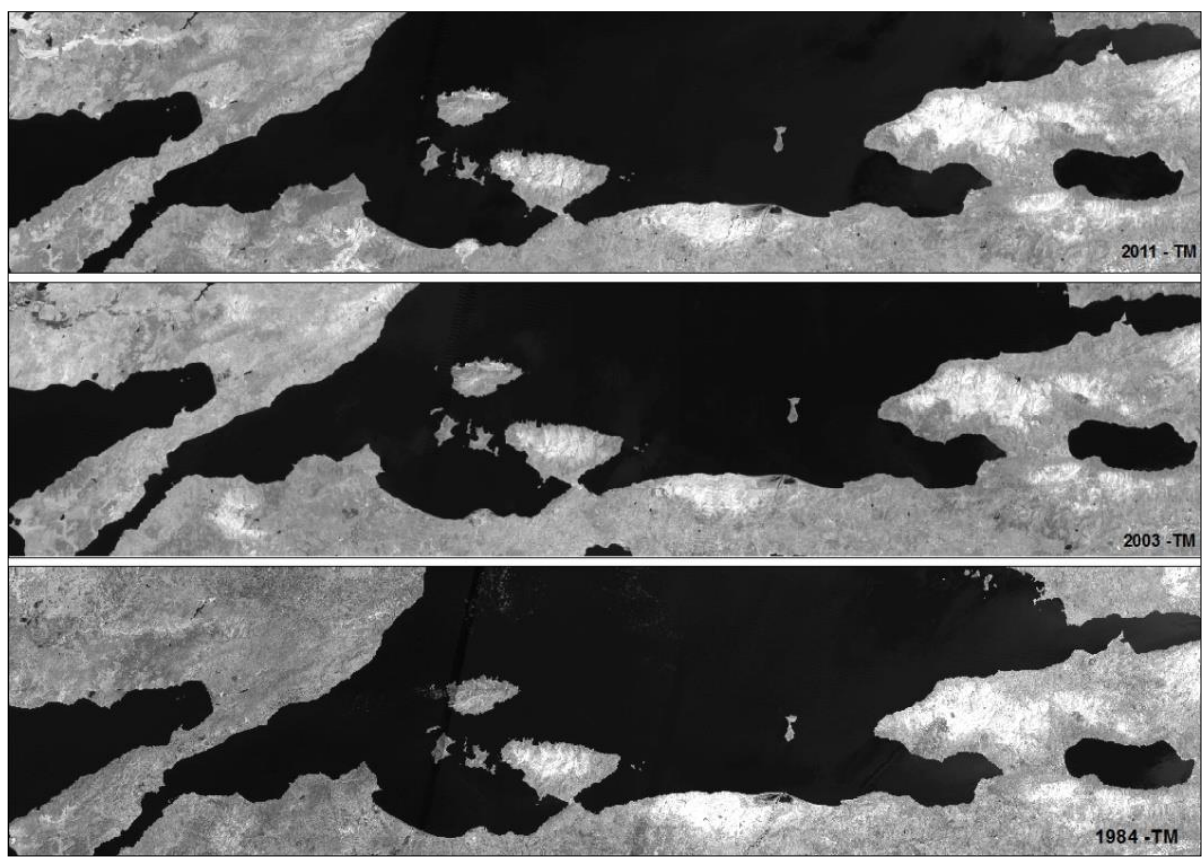

Figure 2: Landsat Satellite Image Used in the Study (Band 4).

Principal Component Analysis (PCA) technique was used due to its capacity to distinguish the difference between land and water in the determination of coastal line of the selected years. PCA is a technique used for the creation of new image after removing the relationship between multispectral images and reducing images in several bands into the desired number of bands (Munyati, 2004, Mausel, 2004; Almutairi and Warner, 2010). This technique is important because it gathers a significant part of the data in multispectral bands 
into the channels of first component and reduces the correlation between image bands. Principal Component Analysis (PCA) is a method preferred in the reduction of the number of bands prior to image compression, image enhancement, change detection and classification (Loughlin, 1991; Akça and Doğan, 2002; Alparslan et al., 2004; Munyati, 2004). Thematic maps (TM), produced as a result, have been transferred to the environment of Geographic Information Systems through the conversion of raster data into vector data. Coastal lines have been revealed as a result of the analyses carried out by the newly-obtained images.

\section{Results And Discussion}

The north and northeast coasts (İstanbul and Kocaeli) of the Marmara Sea, which are under intensive industrial and population pressures, have been confronted with an enourmous change by being negatively affected due to improper development practices and intensive use. In order to prevent this, new areas were added to these areas by performing coastal fillings with the Reconstruction Act passed in 1984 and coastal areas have been tried to be expanded (KK; 1984; Gülez, 1997; Gülkal, 2004; Dede et al., 2004; Kurt et al., 2011; Döker, 2012; Kurt, 2012). Approximately an area of $3 \mathrm{~km}^{2}$ was acquired from the sea through filling as a result of the work covering the period of 19632005. Coastline was changed by filling an area of 906 hectares between 1987 and 2007 (Döker, 2006; Kurt et al., 2010).

Other areas, where change in coastline can be seen as a result of similar land uses although at a lesser extent than the northern coasts, are the southern coasts of the Marmara Sea. They have been opened for intensive use in many places due to improper development practices and this caused the occurrence of coastal changes. A temporal change has taken place along the coastline starting from Çanakkale-Çardak and continuing until Yalova-Kocaeli provincial border due to filling operations. It was observed when looking at satellite images of 1984 and 2008 that coastline trailed the present coastal road in many places, but the original coastline was changed especially in the shorelines of city centers by landfills as seen in the images of next period, namely 2003 and 2011 (Photo 1; Figure 3).

The coasts of Yalova Province are one of the areas where the change in coastline can clearly be seen and which is located on the east of the research area between 39-40 northern latitudes and 29-61 eastern longitudes. Yalova, which has an area of $847 \mathrm{~km}^{2}$ and a coastline of $126 \mathrm{~km}$ in length, is a coastal settlement inhabited by 220.122 people (TSI, 2014). 


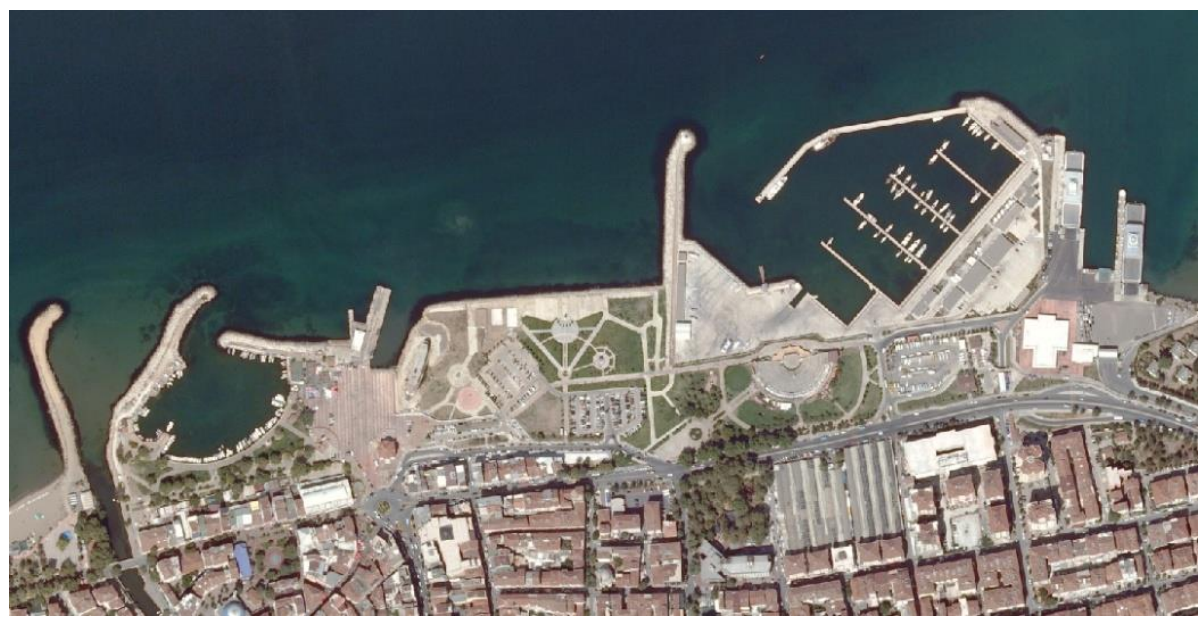

Photo 1: Coastal Filling Area of Yalova City Center (Orthophoto Image of 2008).

The landfills in the coasts of Yalova were being made between 1984 and 2003 and, on the other hand, they also continued and were completed between 2003-2011 when comparing the results obtained from Landsat satellite data of the years 1984-2003-2011 (Figure 3). An area of $0.4 \mathrm{~km}^{2}$ between the years 1984 and 2003, and $1.94 \mathrm{~km}^{2}$ between the years 2003 and 2011 were acquired from the sea due to landfills. As a result of this, the coastline, which was $116 \mathrm{~km}$ in 1984, has reached to $126 \mathrm{~km}$ in 2011 (Tables 2 and 3). The reason why the most prominent change in coastline was observed between the years of 2003 and 2011 was because Yalova had become a province in 1994 and settlements in coastal regions, roads, touristic and industrial organizations have continued to increase as a result of the immigration the province attracted (Özdemir and Bahadır, 2008; Kurt and Haybat, 2014). During this period, fishing port, marina, ferry dock and green spaces were built in an area of 11 hectares according to the filling plans made with the aim of building a shipyard (Boat Berth, Construction, Maintenance and Repair) in the area between Topçular PierTavşanlı District and Hersek Cape and approved by Ministry of Public Housing as well as several other sub-scale development plans accepted in 2005 (7069). An area of approximately $362.000 \mathrm{~km}^{2}$ was filled only in the coasts of central district of Yalova province between 1984-2011 according to 1:1000 scale Development Plans of Housing and Urbanization Directorate of Yalova Municipality (Erdem, 2014). 
Kurt, S./JSS 15(3) (2016):899-924

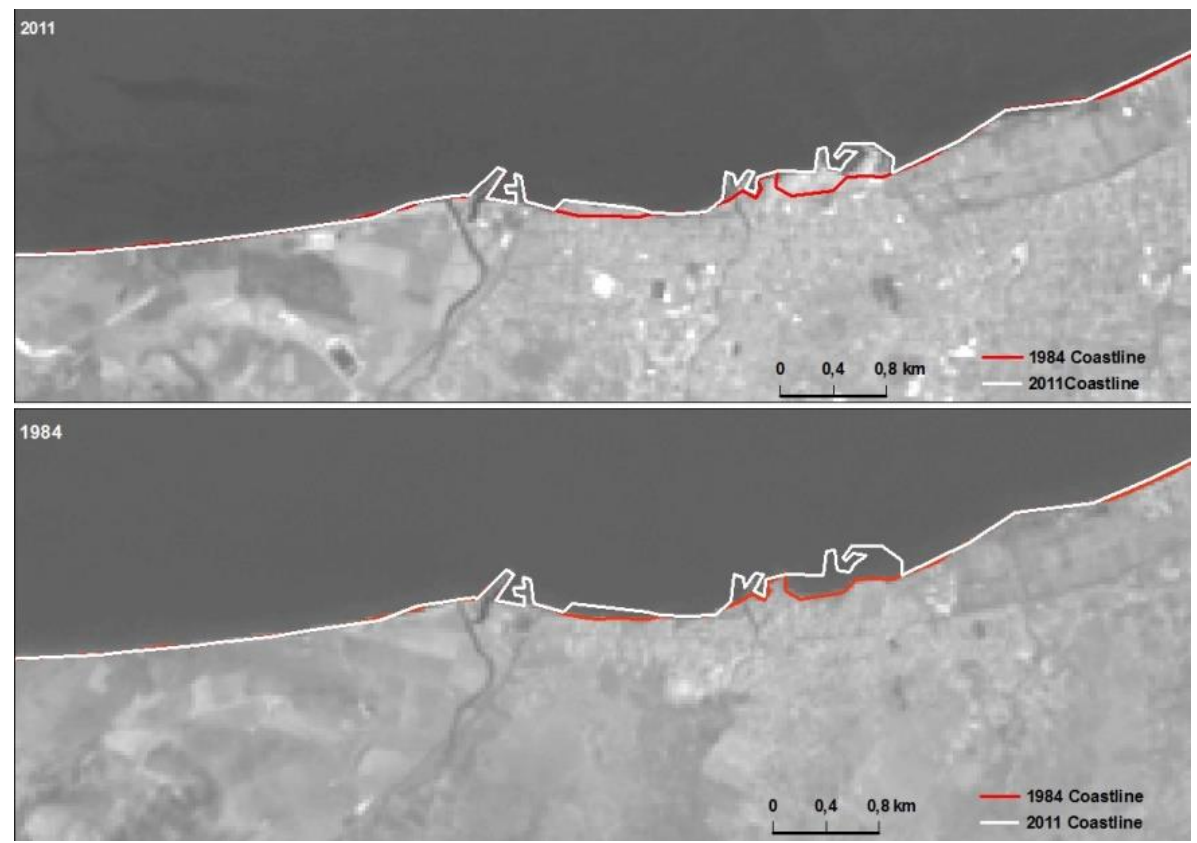

Figure 3: Coastline Evolution in Yalova Coast During the Period 1984 - 2011.

Table 2: Coastal Change (1984-2003)

\begin{tabular}{|c|c|c|c|c|c|c|}
\hline City & $\begin{array}{c}\text { Filling } \\
\text { Area } \\
\left(\mathrm{km}^{2}\right)\end{array}$ & $\begin{array}{l}\text { Beach } \\
\left(\mathrm{km}^{2}\right)\end{array}$ & $\begin{array}{c}\text { Excevation } \\
\left(\mathbf{k m}^{2}\right)\end{array}$ & $\begin{array}{c}\text { Coastal } \\
\text { Length } \\
(\mathbf{k m}) \\
(1984)\end{array}$ & $\begin{array}{c}\text { Coastal } \\
\text { Length } \\
(\mathbf{k m}) \\
(2003)\end{array}$ & $\begin{array}{c}\text { Coastal } \\
\text { Length } \\
(\mathrm{km}) \\
(2011)\end{array}$ \\
\hline Çanakkale & 0,42 & 0,86 & 0,05 & 110 & 110 & 117 \\
\hline Balıkesir & 0,57 & 0,03 & 0,21 & 183 & 186 & 193 \\
\hline Bursa & 0,68 & 0,37 & 0,21 & 112 & 120 & 124 \\
\hline Yalova & 0,4 & 0,02 & 0,005 & 116 & 119 & 126 \\
\hline Total & 2,07 & 1,28 & 0,475 & 521 & 535 & 560 \\
\hline
\end{tabular}

Table 3: Coastal Change (2003-2011).

\begin{tabular}{lcccccc}
\hline City & $\begin{array}{c}\text { Filling } \\
\text { Area } \\
\left(\mathbf{k m}^{\mathbf{2}}\right)\end{array}$ & $\begin{array}{c}\text { Beach } \\
\mathbf{( \mathbf { k m } ^ { 2 } )}\end{array}$ & $\begin{array}{c}\text { Excevation } \\
\mathbf{( \mathbf { k m } ^ { 2 } )}\end{array}$ & $\begin{array}{c}\text { Coastal } \\
\text { Length } \\
\mathbf{( k m )}\end{array}$ & $\begin{array}{c}\text { Coastal } \\
\text { Length } \\
\mathbf{( \mathbf { k m } )}\end{array}$ & $\begin{array}{c}\text { Coastal } \\
\text { Length } \\
\mathbf{( k m )}\end{array}$ \\
\hline Çanakkale & 0,44 & 0,27 & 0,02 & 110 & 110 & 117 \\
Balıkesir & 0,68 & 0,26 & 0,01 & 183 & 186 & 193 \\
Bursa & 0,63 & 1,57 & 0,012 & 112 & 120 & 124 \\
Yalova & 1,94 & 0,03 & 0,008 & 116 & 119 & 126 \\
Total & 3,69 & 2,13 & 0,05 & 521 & 535 & 560 \\
\hline
\end{tabular}

The coastal usage in filled areas has been utilized as transportation, shopping and recreation (Photo 2). The road, built in the meeting place of the 
filling area and land, provides service for vehicle traffic. Recreation areas, pedestrian walkways, bike paths, sports fields and children's playgrounds extending parallel to the coast can be found between highway and new coastline. However, these areas are under great risks due to both ground conditions and their proximity to the fault line (Alpat, 1999; Şahin and Tari, 2000; YÜksel et al., 2000; Tercer, 2005).

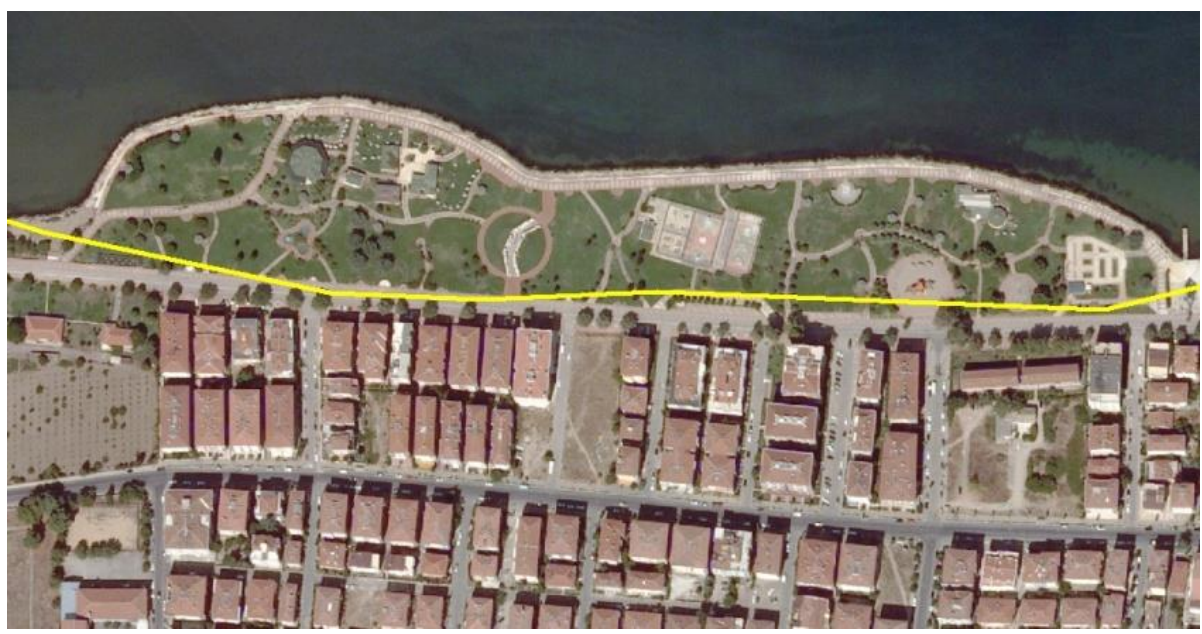

Photo 2: Orthophoto Image of the Filling Area on the West of Yalova and Coastline of 1984.

Today, a coastline of approximately $5 \mathrm{~km}$, which covers agricultural, touristic and residential areas in Altınova (Tavşanlı) region of Yalova Province, is planned to be made a ship-building yard after having been filled. Within the scope of the project, an area of $4.5 \mathrm{~km}$ in length and 300 meters in width, which remains on the sea-side of the coastline in the Civil Administration borders of Altınova district, is planned to be allocated for establishing ship-building yards, and social facilities and industrial areas in the background after being filled and ground filling operations were completed in 2008 (Figure 4). However, the area should be utilized for solution purposes due to environmental issues, pollution, agricultural activites, touristic and earthquake risks as well as ground problems when considering the long-term negative effects of improper use in coastal areas (Alpar, 2005; Yalman, 2012; Report of Yalova Governorship, 2014).

One of the coastal areas in Yalova province, where landfills were carried out although less than northern coasts, is the coast of Armutlu district in the south. The coastline and coastal appearance have changed as a result of the housing activites and filling operations that become a current issue in coastal regions of Armutlu which has the characteristics of a coastal settlement that meets with the holiday needs of metropolitan cities especially İstanbul due to its natural features and geographical location. 
One of the areas seen the change of the coastal line and the coastal area of Hersek Delta. Hersek Delta protruding into the Gulf of Izmit where the intensive usage of coastal and changes of coast in regions of Turkey. Eastern of Hersek Delta has as well as for the long term development of the natural morphodynamic of the delta that have occurred over the last 10 years within the process of the humanities, where the changes originated in the area.

The coasts of Çınarcık, Çiftlikköy, Altınova and Central district are seen to be at risk when considering $86.7 \%$ of total population (183.639 people) in Yalova live in the coastline (Kurt ve Haybat, 2014). Damages in $12 \%$ of the housing (9474 units) and $10 \%$ of the businesses (726 units) after the Marmara Earthquake of August 171.999 as well as the loss of 3000 lives during the earthquake also confirm this situation (Yüksel et al., 2000; Şahin and Tari, 2000; JICA, 2004; Alparslan et al., 2004; Bulut and Aktar, 2007; Özdemir and Bahadır, 2008; Alarslan, 2011). This region is expected to face significant risks in the next earthquake that will occur within the Sea of Marmara due to factors such as liquefaction, subsidence, and deformation of soft alluvial clay layer in the coastal structures and port management built on the landfills located within the domain of the (Yüksel et al., 2000; YIlmaz, 2005).

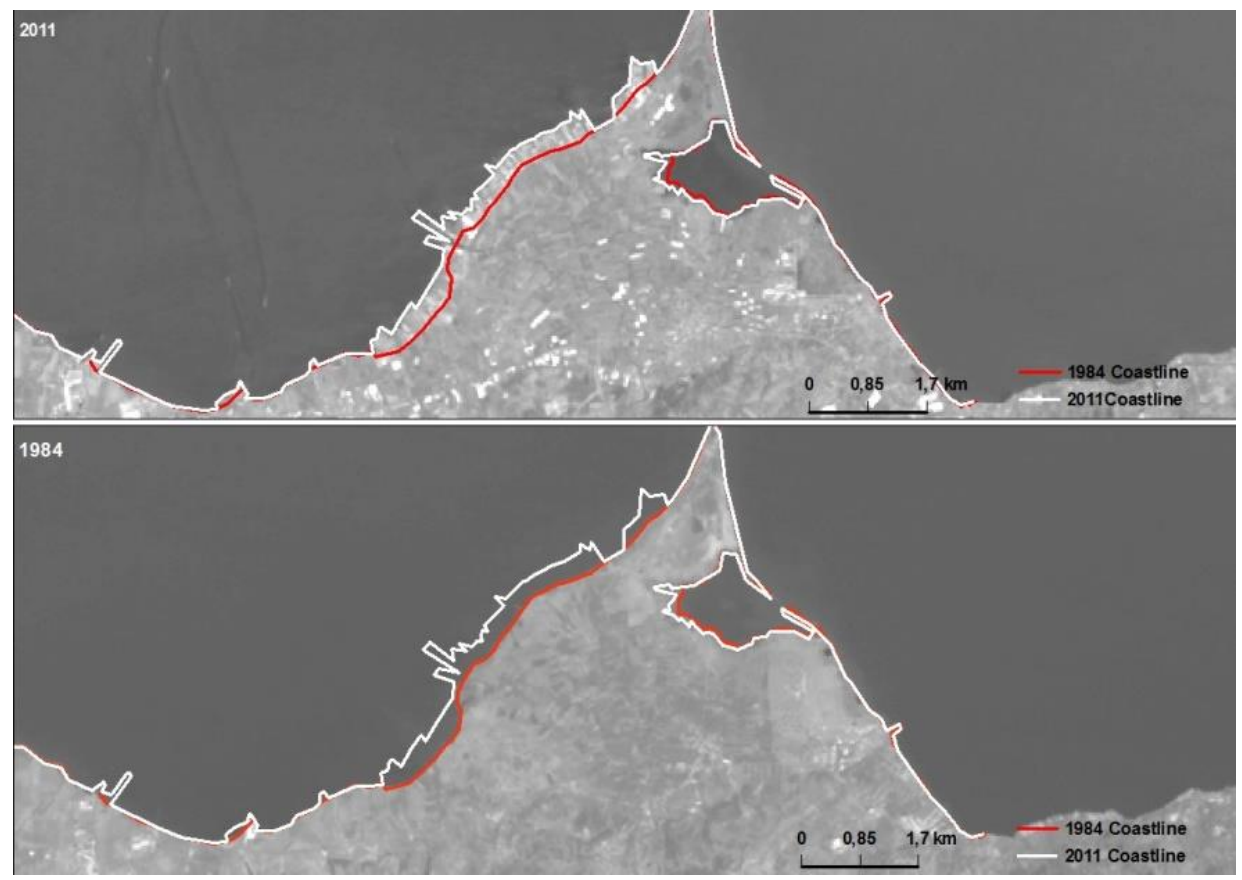

Figure 4: Coastline Evolution in Altınova Coast during the Period 1984 - 2011.

The coastline is seen to change with the coast filling operations in Gemlik and Mudanya districts of Bursa in the coasts of the Marmara Sea when satellite images of the years 1984, 2003, and 2011 as well as the coastlines 
obtained from these were analyzed (Figure 5). An area of $0.68 \mathrm{~km}^{2}$ between the years 1984 and 2003, and $1.31 \mathrm{~km}^{2}$ between the years 2003 and 2011 were acquired from the sea due to landfills (Tables 2 and 3). Landfills were being made in an area of $4000 \mathrm{~m}^{2}$ with the length of $1200 \mathrm{~m}$ and widths ranging between 20 and $50 \mathrm{~m}^{2}$ according to the data from of Science Affairs Directorate of Gemlik Municipality. The greening and landscaping work on the filled grounds still continue (Gemlik Municipality, 2014). The coastline, which was $112 \mathrm{~km}$ in 1984, has reached $124 \mathrm{~km}$ in 2011 with the effect of the landfills (Table 4).

Table 4: Coastal Change (1984-2011).

\begin{tabular}{lcccccc}
\hline City & $\begin{array}{c}\text { Filling } \\
\text { Area } \\
\left(\mathbf{k m}^{\mathbf{2}}\right)\end{array}$ & $\begin{array}{c}\text { Beach } \\
\left.\mathbf{( k m}^{\mathbf{2}}\right)\end{array}$ & $\begin{array}{c}\text { Excevation } \\
\mathbf{( \mathbf { k m } ^ { 2 } )}\end{array}$ & $\begin{array}{c}\text { Coastal } \\
\text { Length } \\
\mathbf{( k m )}\end{array}$ & $\begin{array}{c}\text { Coastal } \\
\text { Length } \\
\mathbf{( k m )}\end{array}$ & $\begin{array}{c}\text { Coastal } \\
\text { Length } \\
\mathbf{( k m )}\end{array}$ \\
\hline Çanakkale & 0,86 & 1,13 & 0,7 & 110 & 110 & 117 \\
Balıkesir & 1,25 & 0,29 & 0,22 & 183 & 186 & 193 \\
Bursa & 1,31 & 1,94 & 0,22 & 112 & 120 & 124 \\
Yalova & 2,34 & 0,05 & 0,01 & 116 & 119 & 126 \\
Total & 5,76 & 3,41 & 1,15 & 521 & 535 & 560 \\
\hline
\end{tabular}

It was observed in the results obtained from its image in 1984 that the coastline, between Gemlik-Mudanya, continued throughout the existing coastal road, but the primary coastline changed in the images belonging to a later period of 2003 and 2011 due to the completed areas of coastal fillings. These landfills serve today as harbor, transportation, shopping and recreational areas. Seabus dock and passgenger terminal can be found on the Güzelyalı coast of the landfill. This dock carries passengers between İstanbul and Yenikapı (Photos 3 and 4). The main road, which partly passes through the acquired land from the sea and partly on the old coast, serves the heavy vehicular traffic in the joining area of the landfills between Gemlik-Mudanya and the land.

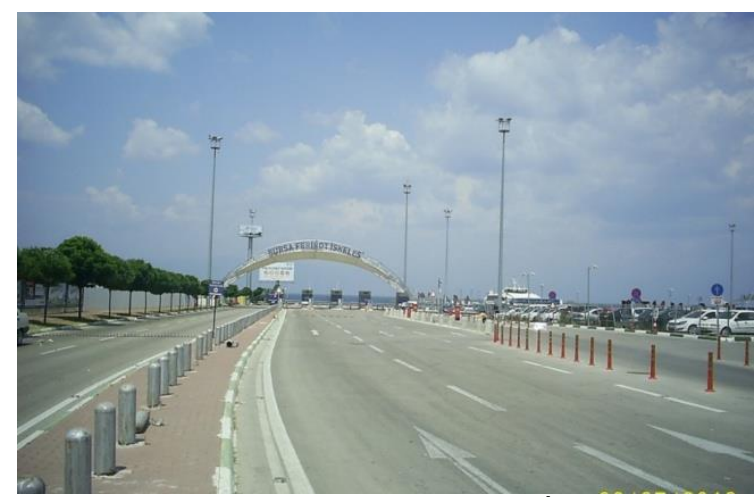

Photo 3: Güzelyalı Seabus Dock where Passage to İstanbul is Provided (2013). 


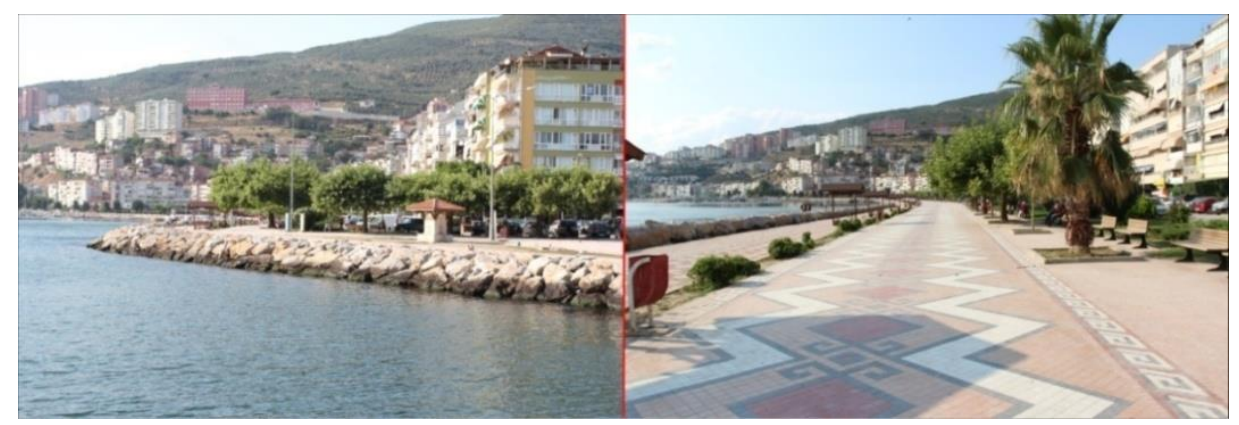

Photo 4: Recreational Filled Area on the Coast of Gemlik (2013).

The length of coastline in Gemlik district, whose coasts are largely filled, is approximately $44 \mathrm{~km}$. Gemlik district, like other port cities on the coasts of Southern Marmara, has been one of the cities which were greatly influenced by port cities such as Bergama, Efes, Milet and Bodrum, in terms of transportation at about 2600 years ago and it still continues to maintain its importance today as an area for sea trade together with 4359 sailors registered in the Port Authority. The length and depth of the Municipality Pier, which was built on the coast for import-export activities, are $125 \mathrm{~m}$ and $6 \mathrm{~m}$ respectively. Gemlik Pier was left for transportation services with the launch of Gemport Port which was built in 1992 as the first private port in Turkey. Other ports, built on the filled ground in the area, are Borusan and Roda Ports (Kamış, 1993; Yalman, 2012; Baki, 2013; Figure 5).

The place, in which the filling operations are the least in the coasts of Bursa at the Marmara Sea, is the district of Karacabey. The filled ground cannot be found in this region except small pier and fishing shelter. However, the coastline was seen to change due to sand removal for construction purposes from the mouth of Kocasu (Kocaçay) river (Figure 6). Sand was confirmed to be extracted from an area of $0.21 \mathrm{~km}^{2}$ between the years 1984 and 2003 and from that of $0.22 \mathrm{~km}^{2}$ between the years 2003 and 2011 in this area (Tables 2, 3, 4). The illegal sand extraction from one of the four areas with international significance and natural reserve features in the coasts of Nortwest Anatolia has disrupted the formation of weir and narrowed the connection between weir gates and the sea (Sayllı et al., 1997; Kazancı et al., 1999). 

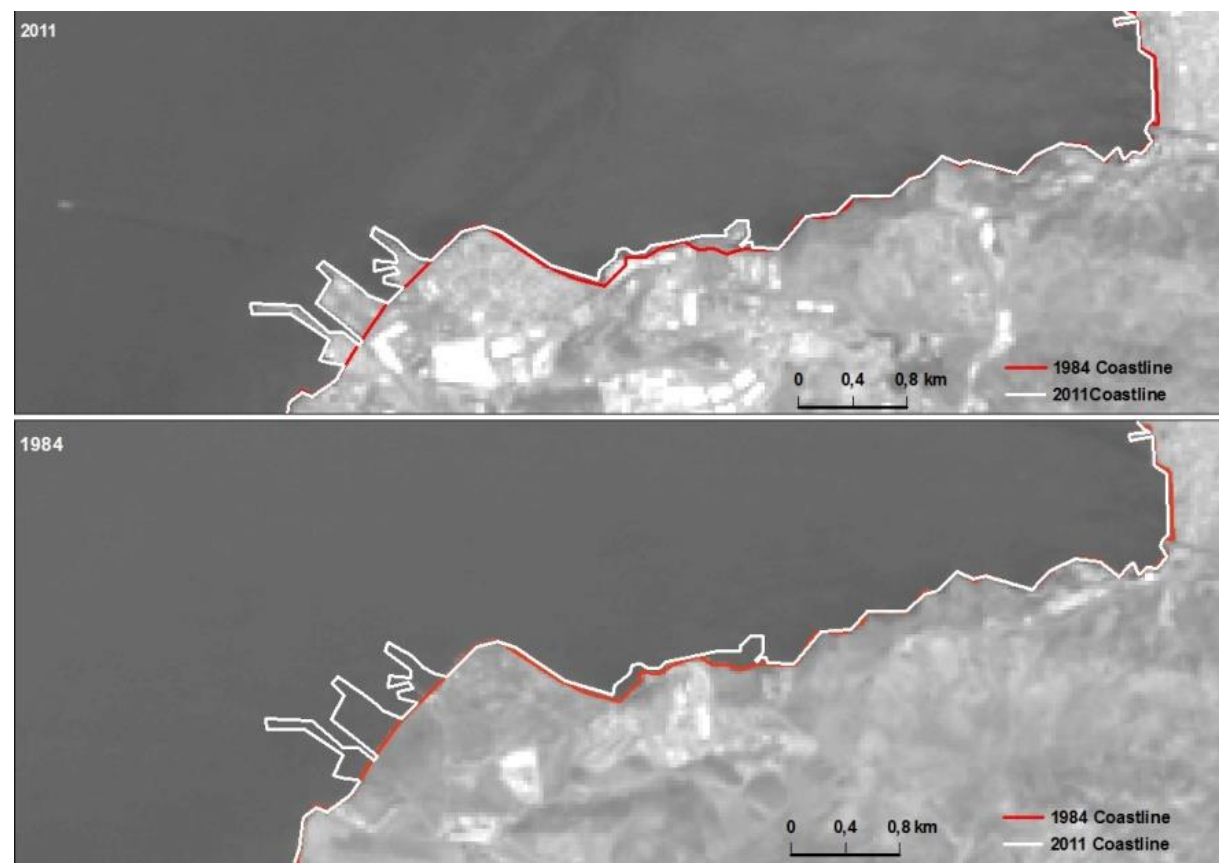

Figure 5: Coastline Evolution in Gemlik Coast during the Period 1984 - 2011.

It is worth-noting when satellite data from the years 1984 and 2011 were analyzed that the coastline is apparent in the coasts of Balikesir at the Marmara Sea especially in the residential areas found in the Gulf of Bandirma and Erdek. The factors, which caused the coastline change in this region, are coast filling operations carried out in the coasts of Bandırma and Erdek districts and sand extractions from the shores of Gönen Stream. The coastline was changed for the purpose of port, pier, road and recreation by filling an area of $0.57 \mathrm{~km}^{2}$ between the years 1984 and 2003, that of $0.68 \mathrm{~km}^{2}$ between the years 2003 and 2011 and an area of $1.25 \mathrm{~km}^{2}$ between the years 1984 and 2011 in total. As a result of this, the coastline, which was $183 \mathrm{~km}$ in 1984, has reached to $193 \mathrm{~km}$ in 2011 (Tables 2, 3, 4).

Bandirma, which is Balikesir's gateway to the Marmara Sea, is the district where the coastline change can be monitored most apparently. The district, which is established in the southern coast of the gulf in $31 \mathrm{~km}$ in length with the same name, is one of the busiest areas of the South Marmara with its surface area of $690 \mathrm{~km}^{2}$ and population of 143.171 people (TSI, 2014). The coastline of 1984 in the coastal band of Bandırma district passes at some places from the residential housings and in front of cliffs yet in other places according to the results obtained from the data and coastline of 1984 . However, the coastline changed with landfills and these structures took cliffs within the coasts (Photo 5). 
Kurt, S./JSS 15(3) (2016):899-924

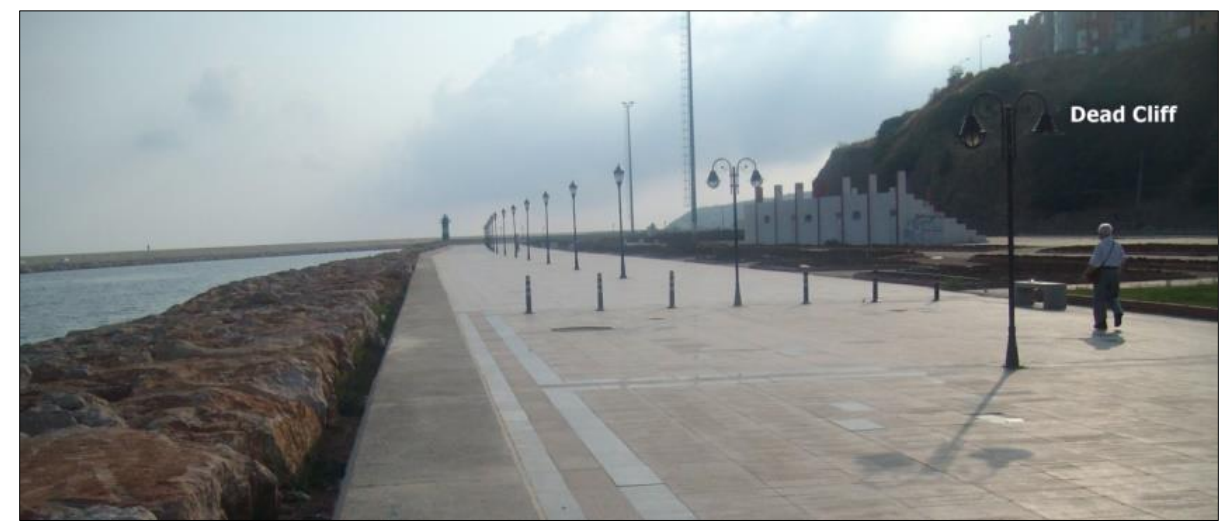

Photo 5: Coastal Landfills that Serve to the People of Bandırma as a Walking Area (2013).

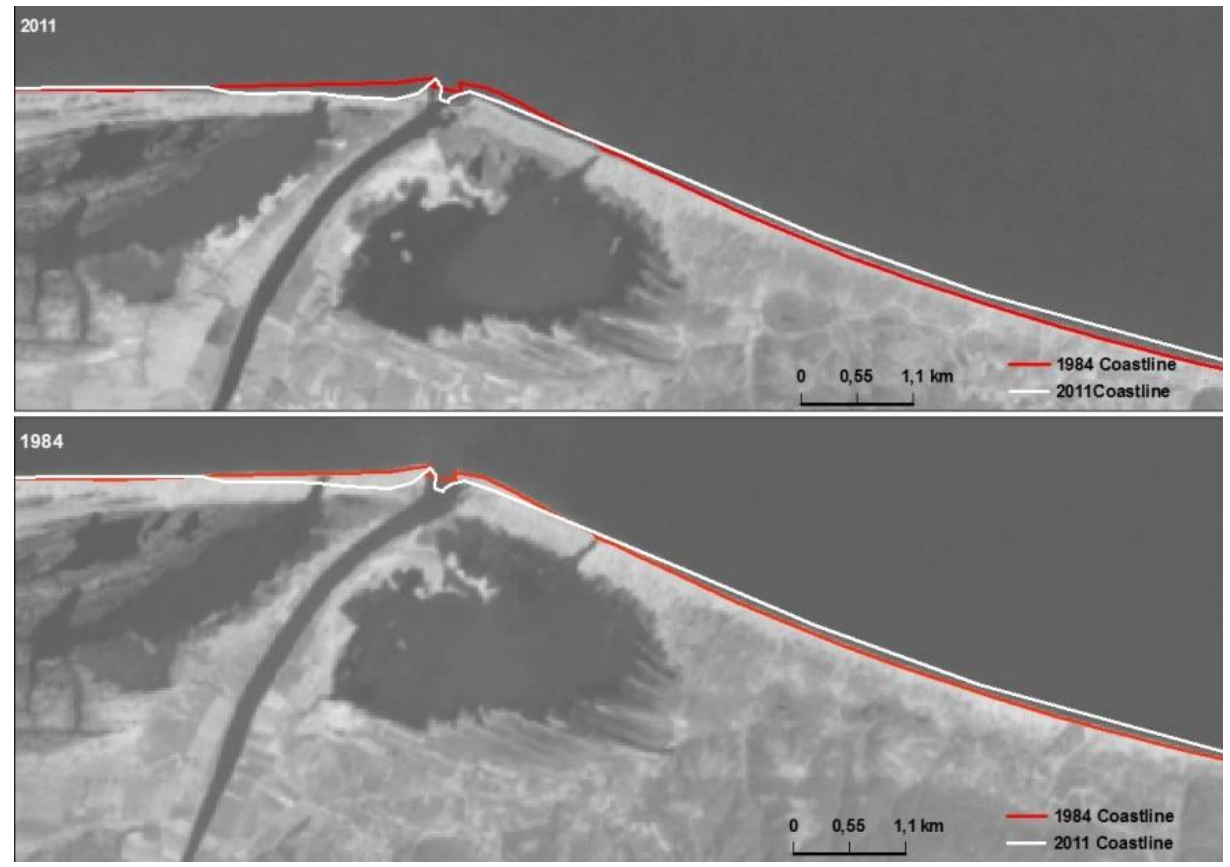

Figure 6: Coastline Evolution in Kocaçay Coast during the Period 1984 - 2011.

Pedestrian excursion and recreational areas, which are located in the area extending from Bandırma Yacht Port to Ferry Terminal and which are built on landfills, also cause change in coastline. Other proofs of historical coastline change are Haydar Çavus Mosque and historical structures located on the coastline of Bandırma coast in 1930. These structures, together with Bandırma Fortress and walls, remained inside with the construction of Bandırma Port and Ferry dock (Photo 6). The coastal change in this region during the construction of Badırma Port was also reflected in the satellite images of 1984-2003. These 
coastal arrangements also continued in these years when looking at the Landsat data obtained in the years of 2003-2011.

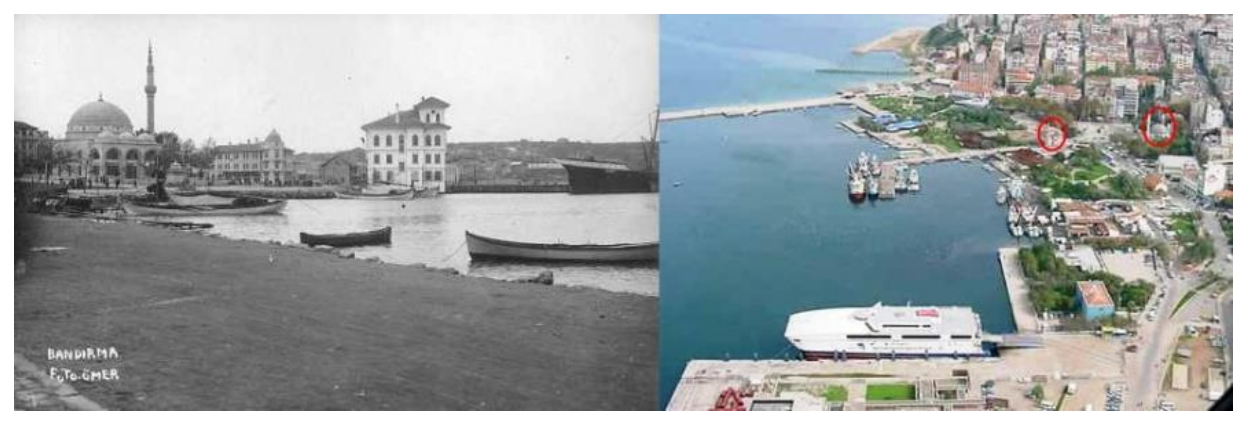

Photo 6: Bandırma Coast in 1930 (on the left) and today (on the right).

Today, various environmental arrangements have been made on the filled area which is situated between IDO Terminal and old pier after preparing a plan that includes touristic and social facilities, recreation and relaxation areas as well as sports facilities (Figure 7). The construction of fishing shelter and environmental arrangements on Levend coast, through a project pursued in 1995 by General Directorate of Railways, Ports and Airports Construction, also confirm that these filling operations still continues (Baykal and Büyükgüllü, 1996; Demir et al., 2000). However, the structures, built on the filled area, are at greatest risk since Bandirma is located on the first degree seismic belt.

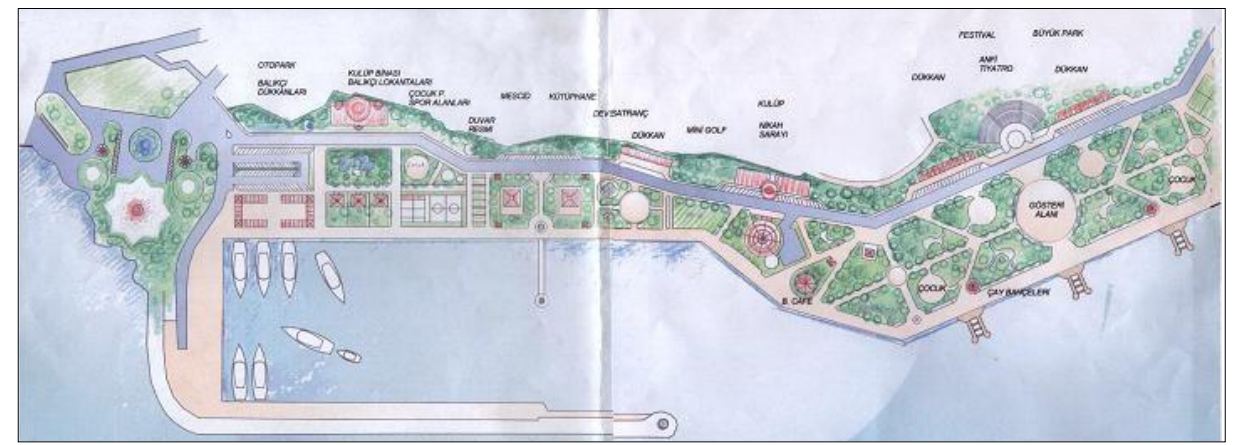

Fıgure 7: Bandırma Coastal Band Project.

Source:http://www.gmka.org.tr/uploads/downloads/dosya/bandirma_ilcesi_bilgi_notu.pdf

Being the most developed district of South Marmara in terms of tourism located on the western coasts of Kapidag Peninsula, Erdek district has long beaches $(6 \mathrm{~km})$ that start from the coasts of Edincik and extend until Çuğra in addition to landfills built on the coasts of city center for recreation and port purposes. The presence of large trade wharf apiece in Greek sea was mentioned in accordance with the information about Erdek obtained from the travels of Evliya Çelebi in 1659. It was suggested about the physical characteristics of Erdek that city had a busy pier on the coast of the sea, its southern coats were 
hilly and its slopes were covered with vineyards throughout (Çelik, 2012; Kurt and Ekinci, 2014).

It was observed when analyzing the satellite data and orthophoto images that there was no change in the coastlines of the northern areas except Erdek and Bandırma Bays of Kapıdağ Peninsula. No landfilles or coastal arrangements were seen in this region except a small pier and fishing shelter.

Gönen district, which has a coastline of $26 \mathrm{~km}$ located on the coast of Balıkesir in the Sea of Marmara, is an area where no landfills can be seen. However, the coastline, especially in the mouth of the river and its surroundings, was seen to change due to sand extraction for construction purposes from an area of $0.22 \mathrm{~km}^{2}$ in the shores of Gönen stream between 1984 and 2011 (Figure 8).

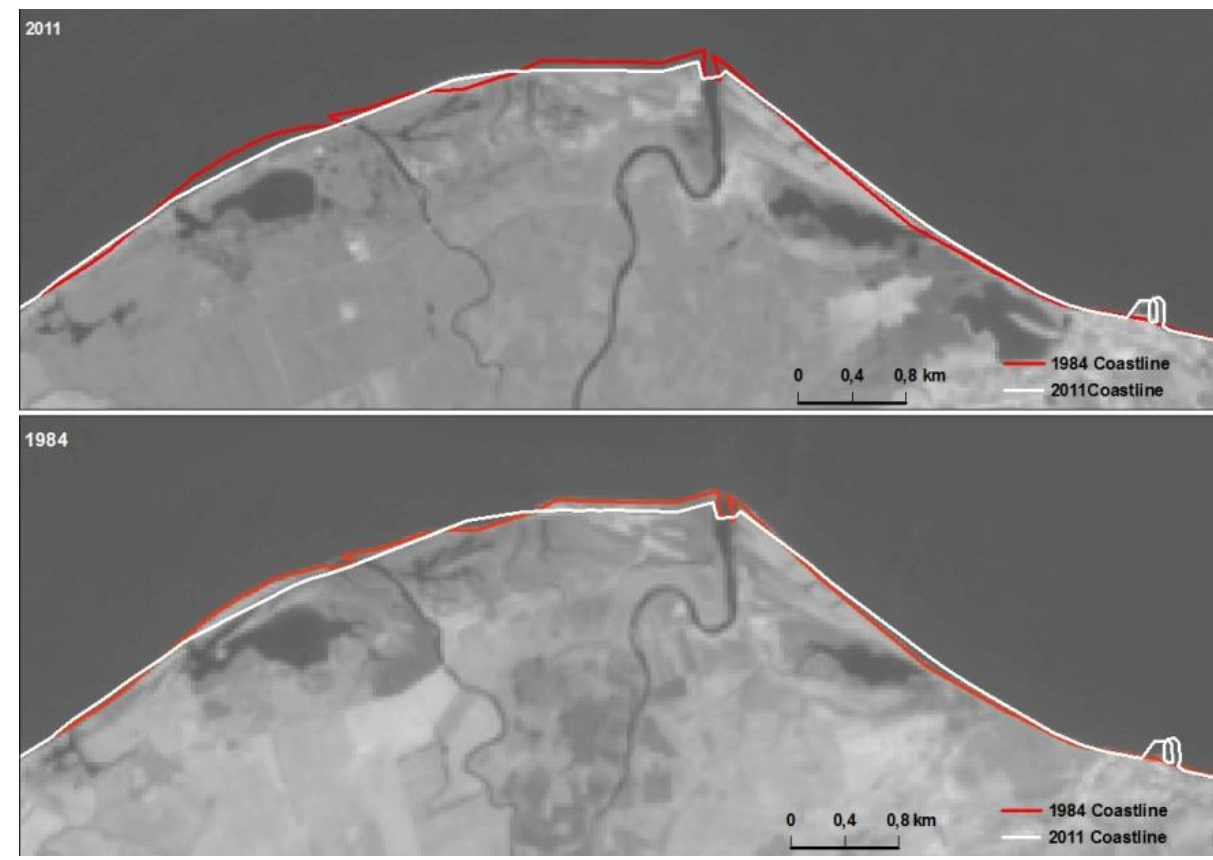

Figure 8: Coastline evolution in Gönen Coast during the period 1984 - 2011.

The coastline change between Çanakkale-Çardak and Balıkesir-Gönen also emerges before us when the satellite data of 1984-2003-2011 were analyzed. The factors that cause the coastline change in this region are the landfills made for the purpose of pier in Lapseki and Biga districts. An area of $0.42 \mathrm{~km}^{2}$ was filled according to the satellite data belonging to 1984 and 2003. A total area of $0.82 \mathrm{~km}^{2}$ was filled due to new arrangements until 2011 and thus the coastline was changed (Figure 9; Tables 2, 3, and 4). While the length of coastline (Çardak-Gönen) in the research area of Canakkale province, which was 
established in an area of $9737 \mathrm{~km}^{2}$ on Gelibolu and Biga Peninsula, was $110 \mathrm{~km}$ in 1984 as a result of these works, it reached $117 \mathrm{~km}$ in 2011(Table 4).

No major change was observed in the coastline between Çardak and Gönen since coastal filling and arrangement operations in the coasts of Çanakkale's research area at Marmara Sea were only in port, pier and fishing shelters. The primary changes in coastline are in the shores of provincial center. The coastline and natural appearance in this region were changed with the construction of yacht marinas and freight and passenger transportation ports, as well as landfills and arrangements for the recreational purposes. For example, Çanakkale Yacht marina, one of the latest arrangements made in the coast, was designed to be built on the filled area of approximately $17852 \mathrm{~m}^{2}$ and on the area of $7667 \mathrm{~m}^{2}$ in the land (Gülver ve Batmaz, 2011).

The coasts of Lapseki and Biga districts mostly consist of holiday resorts for touristic purposes. The arrangements, which were made in Dalyan and Çardak Beaches in the West, Şevketiye Holiday Resort, Gürecealtı, Adatepe and Suluca and throughout the coasts of Kemikalan and Kangırlı, meet the needs of both the locals and the tourists. Çardak Sand Sets, Azmak Laguna Lake, Çardak Natural Protected Area, Bayramdere Archaeological Site and Dalyan Archaeological sites are also other important areas (Veznikli et al., 2007; Akdemir et al., 2008). Biga district, which has the longest coasts of Çanakkale province, covers $10.65 \%$ of total coastal length of Çanakkale with the length of $71.6 \mathrm{~km}$ (Strategic Plan, 2013). The coastline was changed by filling an area of $044 \mathrm{~km}^{2}$ in district shores for the purpose of building pier.

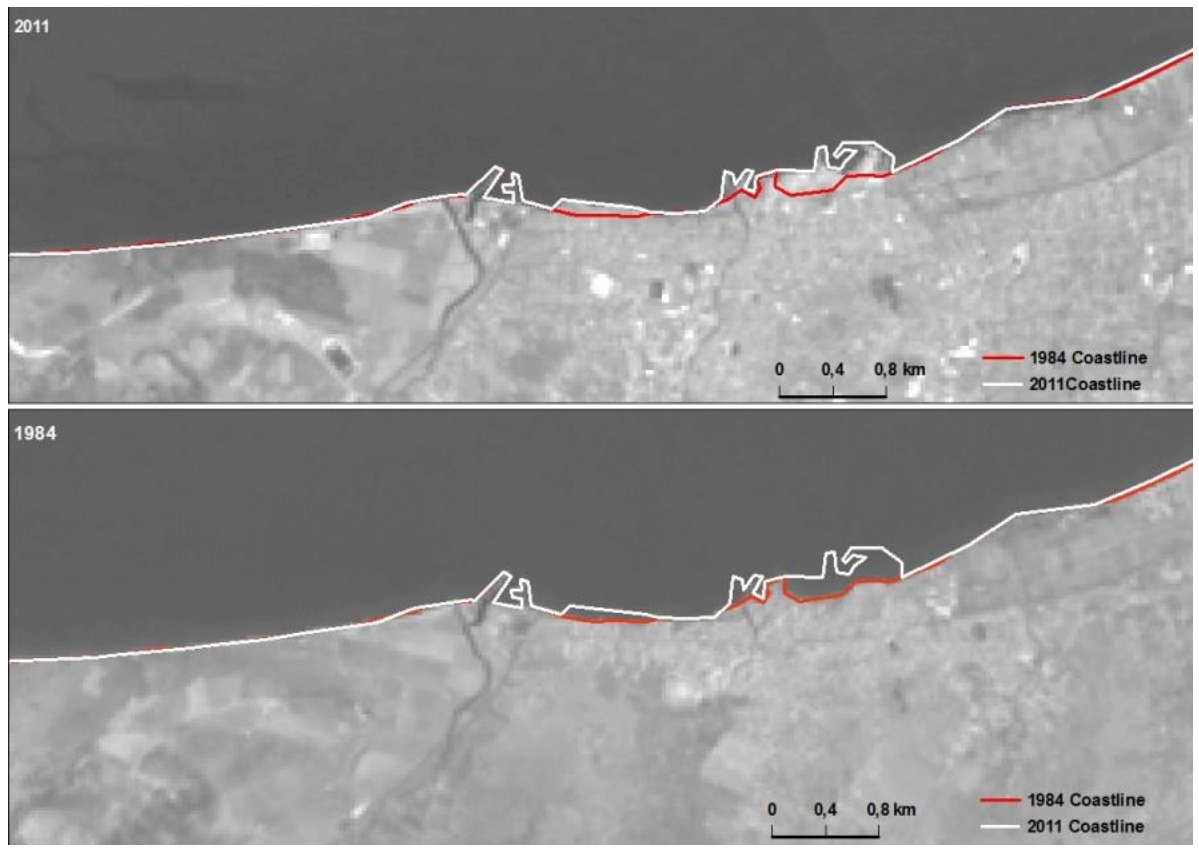


Figure 9: Coastline evolution in Degirmencik (Biga) Coast during the period 1984 - 2011.

There is a sand and gravel accumulation in the shape of fish hook with the length of $4.3 \mathrm{~km}$ in an area of $15-45 \mathrm{~km}$ in width located on the coast of Çardak towards Dardanelles (Figure 10). A lagun and lake of $400-800 \mathrm{~m}$ in width and $4 \mathrm{~km}$ in length were formed behind this set due to acculumation of gravel and sand in $2.5 \mathrm{~km}$ southwest carried by Bayramdere, which is $5 \mathrm{~km}$ in the east of Çardak, to the Marmara Sea. It has been declared as a natural protected area in order to prevent the deterioration of natural landscape by extracting sand from the coasts of the area with its rare reeds and grasses (Atabey, 1998).

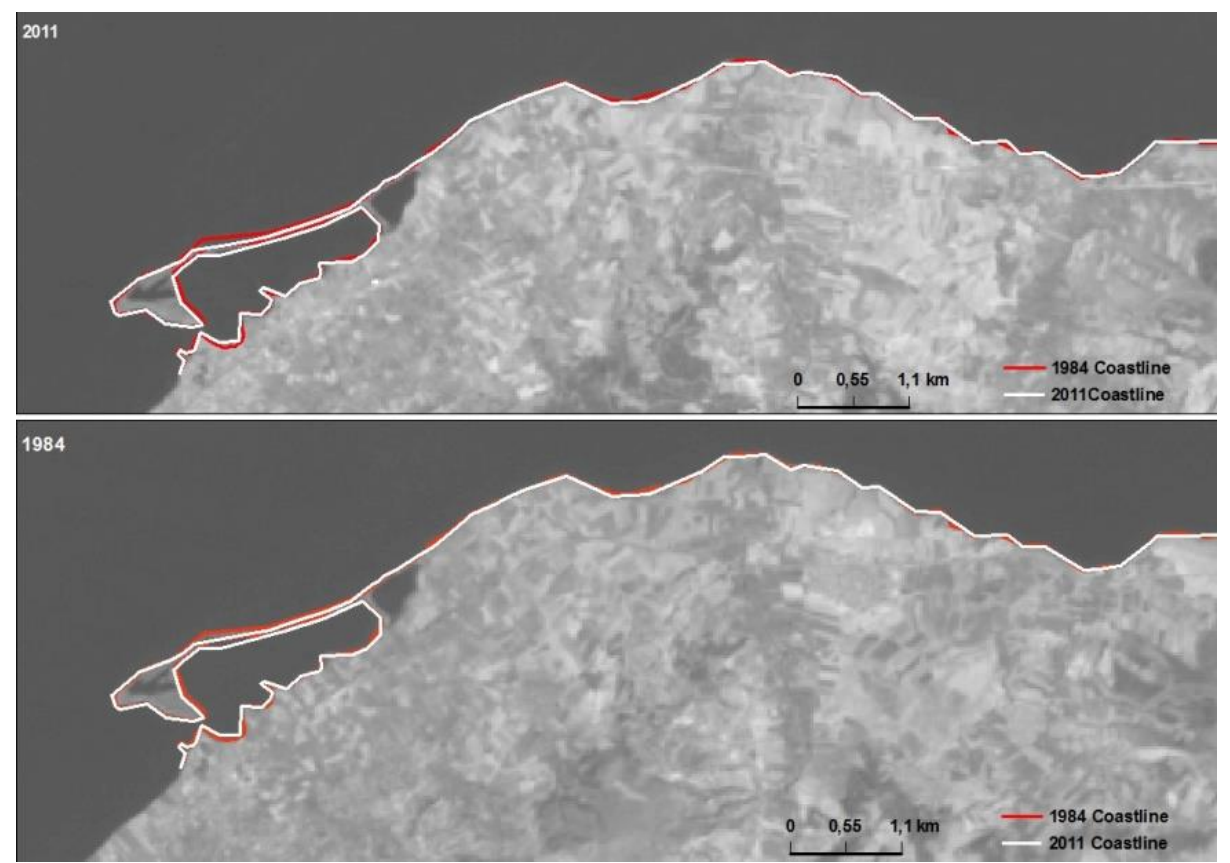

Figure 10: Coastline Evolution in Çardak Coast During the Period 1984 - 2011.

\section{Conclusion}

The change in the southern coasts of the Marmara Sea was determined by using backdated temporal satellite data (Landsat satellite data of 1984-20032011) in this study conducted using Remote Sensing and Geographic Information Systems methods. As a result of the analysis from these data, the coastal length between Çardak-Yalova, which was $521 \mathrm{~km}$ in 1984, was identified to be $560 \mathrm{~km}$ in 2011 when looking at the southern coats of the Marmara Sea. An area of approximately $5.76 \mathrm{~km}^{2}$ was acquired from the sea through landfilling. In this study, the most obvious coastal change was seen to be in the coasts of Yalova, Gemlik, Mudanya and Bandırma. The coastal bend, 
located in Lapseki, Gelibolu, Gönen, Karacabey and in the south of Kapıdağ Peninsula, still remains to be a natural coastline.

Coastal landfills are generally used as recreation, transportation, accommodation and shopping areas. The landfills for recreational purposes comprise of usages such as pedestrian and bicycle paths, tea gardens, children's playgrounds and recreation and picnic areas. Units of sea transportation and coastal road located just behind the coast attract attention in the areas allocated for the use of transportation.

Even though irregular settlements in the coastal areas of cities cut off people's contact with the sea, the solution of filling the coasts was found for the purpose of recreating green spaces in the interest of the public. However, the coastal areas, which have sensitive ecological features, face with pressures of tourism and urban-based developments due to these landfills in the coasts. Therefore, coastal landfills in the southern coasts of the Marmara Sea gradually destroy the natural coastal spaces and the coastline also lost its original appearance. Since no study was found on the prevention of coastline change in the research area, this increases the possibility for the continuation of coastline changes in the future. However, the coasts are one of the areas to conduct studies on the preservation of the natural environment.

Other issues that draw attention in the research area are the existence of active faults in the Marmara Sea and its surroundings and damages to the buildings in Yalova in the Gölcük-centered earthquake in 1999. This case reveals a great risk in landfills. The coastal areas will suffer greatly due to waves to be occurred in the coast as a result of the earthquake. Although how much was the risk for landfills that will come up as a result of seismicity not known before the earthquake of 1999, this risk is needs to be considered for current landfills. Settlements and housing should be shifted from the coastal areas to inner lands due to the risk of earthquake.

Preserving ecological balance and providing sustainability of natural environment should be aimed while making coastal landfills and by preventing housing in the coasts.

It is necessary to carry out actions intended to preserve these nonrenewable natural resources that are damaged due to rapid population growth and housing associated with industrialization, to approach problems with an insightful perspective, to make accurate planning, and to implement necessary solution suggestion in place and on time. 
Kurt, S./JSS 15(3) (2016):899-924

\section{References}

Akça, D., Doğan, S. (2002). The Principal Components Transformation on Digital Images, Map Journal, (129): 1-15.

Akdemir, A., Demircan, O., Yılmaz, S., Takaoğlu, T., Ildııı, M. (2008). Lapseki with Economic, Cultural and Social Value, Lapseki Value Symposium, 27-28 August 2008, Çanakkale, Onsekiz Mart University Publications, (81): 23.

Akova, B.S. (2009). Population in Eastern Mediterranean Coast, Çantay Kitapevi, İstanbul.

Alarslan, E. (2011). Disaster Mitigation Through GIS Technology-Application of Gis Tools to Yalova, A Case Study, GI4DM Workshop, http://www.isprs.org/proceedings/2011/Gi4DM/CDDATA/index.html

Almutairi, A., Warner, T. A. (2010). Change Detection Accuracy and Image Properties: A Study using Simulated Data, Remote Sensing (2): 1508-1529, doi: 10.3390/rs2061508.

Alonso, A.J., Cabrera, L. (2008). Tourist Resorts and Their Impact on Beach Erosion at Sotavento Beaches, Fuerteventura, Spain, Journal of Coastal Research, SI 36, 1-7 (ICS 2002 Proceedings) Northern Ireland ISSN 0749-0208.

Alpar, B. (2005). Seismic Evaluation of Yalova-Altınova Coast Shipyard Area Being Requested, Earthquake Symposium, 23-25 March 2005, Kocaeli.

Alparslan, E., Dönertaş, E. A., Yüce, H. (2004). Change Analysıs on The Yalova Province's Coastal Settlement from Satellite Images, Fatih University $3^{\text {rd }}$ GIS Days in Turkey, 6-9 October 2004, Istanbul.

Arpat, E. (2005). Causes of Deformation Occurring Outside of Break of The Main Faults in The Kocaeli 1999 Earthquake, Earthquake Symposium, 23-25 March, 2005, Kocaeli.

Anfuso, G., Martı'nez-del-Pozo, J. A', Rangel-Buitrag, N. (2013). Morphological Cells in the Ragusa Littoral (Sicily, Italy), 17:369-377. doi:10.1007/s11852-0130233-8

Anilkumar, P. P., Koshy, V., Ganesh, L. S., (2010). Formulating A Coastal Zone Health Metric For Landuse Impact Management in Urban Coastal Zones", Journal of Environmental Management, (91): 2172 - 2185.

Atabey, E. (1998). Historical and Geological Heritage: Pavilions Sand Set and Lagoon, Journal of Science and Technology, Çardak Municipal Promotion and Cultural Service.

Baki, G. (2013). The Characteristics and Problems of Gemlik District's Economic Geography, Atatürk University, Institute of Social Sciences, Department of Geography, Master Thesis, Erzurum. 
Baykal, M., Büyükgüllü, M. (1996). Bandırma Fishing Shelter Coordinated General Plan (1:1000), BBB-002, Ministry of Transport Railways, Ports and Airports Construction General Directorate, Ankara.

Demir, H., Savran, S., Otay, E.N. (2000). Alternatively Coast Filling Project Feasibility Study, 3rd National Coastal Engineering Symposium, pp. 403-417, 56-7 October 2000, Çanakkale

Boak, H. E., Turner, L., Lan. (2005). Shoreline Definition and Detection: A Review, Florida, Journal of Coastal Research, 21(4): 688-703.

Brommer, M., B., Bochev-Van Der Burgh, L., M. (2009). Sustainable Coastal Zone Management: A Concept for Forecasting Long-Term and Large-Scale Coastal Evolution", Journal of Coastal Research, 25(1): 81-188.

Bulut, F., Aktar, M. (2007). Accurate relocation of İzmit earthquake (Mw = 7.4, 1999) Aftershocks in Çınarcık Basin Using Double Difference Method, Geophysical Research Letters, (34): 1-4.

Cardille, J.A., Foley, J.A. (2003). Agricultural Land-Use Change in Brazilian Amazonia between 1980 and 1995: Evidence from Integrated Satellite and Census Data, Remote Sensing of Environment, 87(4): 551-562.

Crowel, M., Scott E., Kevin, C., Scott, M. (2007). How Many People Live in Coastal Areas?, Journal of Coastal Research, 23(5): iii-vi.

Çelik, Ş. (2012). Information and Their Value Given by the Evliya Çelebi about Bandırma, Aydın (Edincik), Balıkesir University, Journal of the Institute of Social Sciences, 15(28-1): 67-81.

Dede, M.O., Ayten, M.A. Yazar, K.H. (2004). An Assessment of The Current Planning System in Coastal Areas Planning, Turkey's Coastal and Marine Areas 5th National Conference, 4-7 May 2004, 04 Turkey Coast Conference Proceedings, 251-258, Adana.

Demir, H., Savran, S., Otay, E. N., 2000. Bandırma Alternatively Coast Filling Project Feasibility Study, III. National Coastal Engineering Symposium, 5-6-7 October, 2000, Proceedings Book, 403-417, Çanakkale.

Demirci, A., Karaburun, A., Kurt, S. (2009). Assessment of Urban Growth in a Natural Protected Area Using Multi-Temporal Satellite Data: A Case Study of the Strait of Istanbul (Bosphorus), Fresenius Environmental Bulletin 18(9a): 17011708.

Doğaner, S. (1992). Tourism Geography of the Gemlik Bay North Coasts, Turkish Journal of Geography, (27): 59-84, İstanbul.

Doğaner, S. (2001). Tourism Geography of Turkey, Çantay Kitapevi, İstanbul.

Döker, M. F. (2006). İstanbul Province, Marmara Sea Determination of Coastal Areas Filling and Land Use in this Fields. İstanbul University, Institute of Social Sciences, Department of Geography, Master Thesis, İstanbul. 
Döker, M. F. (2012). Determination Temporal Changes of the Coastline of the Sea of Marmara in İstanbul, International Journal of Human Sciences (Online), (9)2: 1350-1370.

Duru, B. (2001). Approach to Integrated Coastal Management and the National Coastal Policy, Ankara. University, Institute of Social Sciences, Department of Public Administration and Political Science (Urban and Environmental Sciences) PhD Thesis, Ankara.

Erdem, M. (2014). Yalova Municipality, Reconstruction Urban Development Directorate, 26125173 Numbered Information Letter, 30. 09. 2014, Yalova.

Erol, O. (1997). Geomorphological Approach to Coastal Usage Problems in Turkey. Journal of Research and Application Center of Geography of Turkey, Issue: 6.

Finkl, C. W. (2004). Coastal Classification: Systematic Approaches to Consider in the Development of a Comprehensive Scheme, Journal of Coastal Research, 20(1): 166-213.

Gazioğlu, C., Yücel, Y., Z., Burak, S., Okuş, E., Alpar, B. (1997). Coastline Change and Inadequate Management Between Kilyos and Karaburun Shoreline, Turkish J. Mar. Üniversity of İstanbul, Institute of Marine Science and Management, 3(2): 111-122.

Gemlik Municipality, (2014). Gemlik Municipality, Reconstruction Urban Development Directorate, 24. 09. 2014, Gemlik.

Genç, İ., Açan, M., Turhan, H., Burak, A. (2010), Determination of Land Cover Using Landsat TM Imagery, Journal of Agricultural Sciences, 16: 213-224.

Gülez, S. (1997). Integrated Planning in Terms of Use-Protection of Coastal Areas, Turkey's Coastal and Marine Areas, 1sht National Conference, 24-27 Jun 1997, Turkey Coasts 97, Conference Proceedings Books, 85-92. Ankara.

Gülkal, Ö. (2004). The Protection of the Coasts Role of Special Environment Protection Zones; Patara Example, Turkey's Coastal and Marine Areas 5th National Conference, 4-7 May 2004, Turkey Coast '04 Conference Proceedings Book, 101-110, Adana.

Gülver, M. A., Batmaz, G. M. (2011). Çanakkale Marina Feasibility Report, Çanakkale Trade and Industry Department Publication, pp. 3, October 2011, Çanakkale.

İrtem, E., Karaman, E. (2004). The Effect of Tourism Activities along EdremitKüçükkuyu Region on The Coastal Area And Proposed Management Program, itu journal /d, Engineering, 3(1): 3-14.

[40] JICA (Japan International Cooperation Agency), (2004). Country Strategy Paper for Natural Disasters in Turkey, Ankara, 6-7.

KK (Kıyı Kanunu). (1984). 27 Novamber 1984 dated and 3086 Number Coastal Law. Newspaper Date: 01 December 1984, Official Gazette No: 18592. 
Kamış B.P. (1993). Functional Areas Distribution and Development Establishment of Gemlik, Ankara University Institute of Social Sciences, PhD Thesis, Ankara.

Kazancl, N., Emre, Ö., Erkal, T., İleri, Ö., Ergin, M., Görür, N. (1999). Kocasu and Gönen River Delta's (Marmara Sea) Actual Morphology and Sedimentary Facies., MTA Journal, 121: 33-50.

Klemas, V.V. (2009). Remote Sensing Techniques for Studying Coastal Ecosystems: An Overview, Journal of Coastal Research, 27(1): 2-17.

Kostiuk, M. (2002). Using Remote Sensing Data to Detect Sea Level Change, Pecora, 15/Land Satellite Information IV/ISPRS Commission I/FIEOS 2002 Conference Proceedings.

Kurt, S., Demirci, A., Karaburun, A. (2011). Coastal Land Use Changes in İstanbul between 1987 and 2007, Eastern Geographical Review, 26: 115-128.

Kurt, S. (2012). Land Use Changes in İstanbul's Marmara Sea Coastal Regions Between 1987 and 2007, Middle-East Journal of Scientific Research, 11(11): 1584-1590.

Kurt, S., Ekinci, D. (2013). The Geomorphotourism Features of The North Coast of Gulf of Erdek", 3rd International Geography Symposium - GEOMED 2013, Symposium Proceedings, 10-13 June 2013, Kemer - Turkey, 450-460.

Kurt, S., Karaburun, A., Demirci, A. (2010). Coastline Changes in İstanbul between 1987 and 2007, Scientific Research and Essays, 5(19): 3009-3017.

Kurt, S., Haybat, H. (2014). Population Distribution by Geomorphological Units in Yalova, Turkish Studies - International Periodical for the Languages, Literature and History of Turkish or Turkic, 9(1): 327-336.

Loughlin, W.P. (1991). Principal Component Analysis for Alteration Mapping", Photogrammetric Engineering \& Remote Sensing, 57(9):1163-1169.

Maktav, D. (1993). Micro Computer Software Recommendations in Remote Sensing and hardware Relationship Evaluation in terms of Economics, suggestions", İTÜ Jounal, 51(3):25-30.

Mausel, D., Brondízio, P., Moran, E. (2004). Change Detection Techniques, International Journal of Remote Sensing, 25(12): 2365 - 2401.

[54] Munyati, C. (2004). Use of Principal Component Analysis (Pca) of Remote Sensing Images in Wetland Change Detection on the Kafue Flats, Zambia", Geocarto International, 19(3):11-22.

Özdemir, A., M., Bahadır, M. (2008). Temporal Change of Land Use in Yalova Province, İstanbul University, Department of the Geography Journal, (17): 1-15.

Özşahin, E., Ekinci, D. (2012). Marmara Sea and Human Delta, Turkey's Coastal and Marine Areas IX. National Congress, 14-17 November 2012, Conference Proceedings Books pp. 325-333, Antakya/Hatay. 
Saïdi, H., Souissi, R., Zargouni, F. (2012). Environmental Impact of Detached Breakwaters on the MediterraneanCoastline of Soliman (North-East of Tunisia), Rend Fis Acc Lincei. doi:10.1007/s12210-012-0191-3.

Saïdi, H., Souissi, R., Zargouni, F. (2010). Impact of shore-parallel breakwaters on the microtidal coast of Hammam-Lif (North-East of Tunisia), Arab J of Geosci. doi:10.1007/s12517-010-0223-1.

Sayılı, I. S., Ergin, M., Şahbaz, A., Özdoğan, M., Varol, B., İleri, Ö., Bayhan, E., Görmüş, S., Turan, S.D., Soydemir, Ö. (1997). The Coastal Beach Sedimentary of the Kocasu Delta's Sedimentological and Mineralogical Features: Preliminary Report, TÜBİTAK YDABÇAG-426/G Project Report, pp. 170-191. (Koord. N. Kazancı and N. Görür), Ankara.

Sayıştay Raporu, (2006). Planning and Control of the Use of Coastal, Court of Auditors Journal, Issue: (62): 148- 150.

Scarfe, B.E., Terry, R.H., Hamish, G.R., and Shaw T.M. (2009). Sustainable Management of Surfing Breaks: Case Studies and Recommendations, Journal of Coastal Research, 25(3): 684-703.

Sesli, F.A., Karslı, F., Çölkesen, İ. (2007). Determination of the Coastline Changes and Use of Remote Sensing, Turkey National Photogrammetry and Remote Sensing IV. Symposium, 5-7 Jun 2007, İstanbul.

Strategic Plan (2013), TC Biga Trade Exchange (2013-2016).

http://www.bigatb.tobb.org.tr/pdf/stratejikplan.pdf, Accessed date: 30.10.2014.

Şahin, M., Tari, E. (2000). The August 17 Kocaeli and the November 12 Düzce Earthquakes in Turkey, Earth Planets Space, (52): 753-757.

Tercan, B. (2005). Resettlement Process in Yalova after Earthquake, Earthquake Symposium, 23-25 March 2005, Kocaeli.

TSI (Turkey Statistical Institute), (2014). "Populating Data", http://www.tuik.gov.tr, Accessed date: 5 October 2014.

Veznikli, N., Gümüş, F., Hamarat, B. (2007). Local People Perspective towards the Assessment of Tourism Research: The Case of Lapseki, Lapseki Symposium07, 23-24 Jun 2007, Çanakkale.

Vinodkumar, K., Bhattacharya, A., Subramanian, C. (1998). Coastal Morphological Influences for Trophical Cyclone Track Deviation along Andhra Coast: GIS and remote sensing based approach Current Science 75(9): 955-958.

Yalman, B. (2012). "Gemlik", Peaceful Agency, 46, Bursa.

Yalova Provincial Administration Governorship (2012). Master Plan Study on the Yalova Province Related to Mining activities, http://www.yalovaozelidare.gov.tr/, Accessed date: 13 December 2013. 
Yalova Governorship Report

http://www.altinovatersane.com.tr/index.php/yalova-valiligi-

(2014). raporu?showall=\&start=1, Accessed date: 14.08.2014

Yılmaz, I., Yavuzer, D. (2005). Liquefaction Potentials and Susceptibility Mapping in the City of Yalova, Turkey, Environmental Geology, 47(2): 175-184.

Yüksel, Y., Özmen, H., Çevik, E., Özgüven, O., Çelikoğlu, Y., Bostan, T., Gürer, S., Gökoğlu, F. (2000). Impacts on the Marine Structures in the Gulf Region of the Eastern Marmara Earthquake Effects, 3rd National Coastal Engineering Symposium, 5-6-7 October 2000, Çanakkale.

Zhu, X. (2001). Remote Sensing Monitoring of Coastline Change in Pearly River Estuary", Assian Conference of Remote Sensing, 5-9 November 2001, Singapore. 